\title{
Industrial Concentration of Ethnic Minority- and Women-Owned Businesses in the United States $^{1}$
}

By

\section{Qingfang Wang University of North Carolina}

\section{CES 13-34 June, 2013}

The research program of the Center for Economic Studies (CES) produces a wide range of economic analyses to improve the statistical programs of the U.S. Census Bureau. Many of these analyses take the form of CES research papers. The papers have not undergone the review accorded Census Bureau publications and no endorsement should be inferred. Any opinions and conclusions expressed herein are those of the author(s) and do not necessarily represent the views of the U.S. Census Bureau. All results have been reviewed to ensure that no confidential information is disclosed. Republication in whole or part must be cleared with the authors.

To obtain information about the series, see www.census.gov/ces or contact Fariha Kamal, Editor, Discussion Papers, U.S. Census Bureau, Center for Economic Studies 2K132B, 4600 Silver Hill Road, Washington, DC 20233, CES.Papers.List@census.gov. 


\begin{abstract}
The number of ethnic minority and women-owned businesses has increased rapidly during the past few decades. However, the characteristics of these businesses and their owners differ by race, ethnicity, and gender. Using a confidential national survey of ethnic minority and womenowned businesses in the United States, this study examines ethnic minority- and women-owned businesses segmented by industrial sectors. Consistent with gender occupational segregation, male- and female- owned businesses have distinctive sectoral concentration patterns, with ethnic minority women- owned businesses highly concentrated in a limited number of industrial sectors. However, the relationship between business sectoral concentration and business performance is not uniform across ethnic and gender groups. Concentration in specific industrial sectors does not necessarily mean poor performance when measured by sales, size of employment or payrolls. However, for women-owned businesses, those sectors obviously pay less and have marginal profits, especially if considering the size of the firms.
\end{abstract}

Keyword: ethnic business, female entrepreneurship, labor market segmentation, gender

${ }^{1}$ Any opinions and conclusions expressed herein are those of the author(s) and do not necessarily represent the views of the U.S. Census Bureau. All results have been reviewed to ensure that no confidential information is disclosed. 


\section{Introduction}

During the past two decades, the number of women-owned businesses has increased dramatically

(Mayer 2008). Studies have shown that owning a business could provide women with a springboard for economic progress and further socioeconomic advancement. Even selfemployment is one of the avenues for the empowerment of some ethnic minority women to break free from traditional gender roles (Handson 2009; Levant et al. 2009). However, there are significant differences observed between female- owned and male- owned enterprises, and between female and male entrepreneurs. For example, women entrepreneurs have fewer financial resources, their enterprises tend to be smaller, grow slower, and appear less successful if measured by economic criteria (Cliff 1998; Kepler and Shane 2007). These gender differences seem consistent with the considerable literature of gender occupational segregation: women frequently are concentrated at the lower level of the labor market hierarchy with low pay and unstable working conditions (England 1981; Farley and Allen 1987; Lieberson and Water 1990; Reskin 1993).

With the diverging trends of women’s entrepreneurial advancement and their continuing disadvantages in the labor market, it is crucially important to further examine women's entrepreneurial activities through the lens of labor market segregation. Are women-owned businesses concentrated in particular economic sectors similar to their occupational segregation? If so, what are the consequences of sectoral concentration in terms of their business performance?

Compared to the extensive literature on gender occupational segregation, both a general profile and the details of the segmentation across industrial sectors for women-owned businesses are relatively unknown. The lack of knowledge of women's business industrial concentration becomes more problematic with continuing racial and ethnic diversification of the urban labor markets. With the continuing influx of immigrants from Latin America and Asia during the past 
several decades, many places in North America that have received large numbers of immigrants have become fertile land for ethnic entrepreneurship (Teixeira 2001; Kaplan and Li 2006). On the one hand, a preponderance of research indicates that entrepreneurship could provide ethnic minorities more avenues for economic progress (Appold and Kasarda 2004; Bates 2006; Furuseth 2010; Portes and Jensen 1989; Zhou and Cho 2010). On the other hand, a racialized labor market process, discrimination, and blocked opportunities in the wage job market have forced some ethnic minority to turn to self-employment or running small businesses (Raijiman and Tienda 2000; Teixeira et al. 2007). Accordingly, an “economic dead-end” perspective argues that ethnic minority ownership provides no automatic social mobility but simply entails “a horizontal shift in which disadvantage is perpetually in another guise” (Barrett et al. 1996, 787). The diverging trend of women business ownership and gender occupational segregation, plus the contrasting view of ethnic minority business ownership, call for a further discussion of industrial division of labor, between men and women, among racial and ethnic groups, and through entrepreneurial economic activities. Schrover et al (2007) have discussed the similarities in the mechanisms and characteristics of gender labor market segregation and ethnic concentration or segmentation. However, a large scale of systematic comparison of business' industrial concentration across ethnic and gender groups are extremely rare. Using a confidential national survey of ethnic minority and women-owned businesses in the U.S., this study focuses on how businesses are concentrated in different industrial sectors across race/ethnicity and gender, and how the concentration or segmentation by the divide of race/ethnicity and gender is associated with business performance.

Findings from this study will directly inform debates between these contrasting views on entrepreneurship, race/ethnicity, and gender. They will also contribute to labor market 
segmentation theories through the lens of entrepreneurship. Through a comparative approach, this study draws a broad picture of entrepreneurship along the lines of race, ethnicity, and gender, which can be compared to existing studies on ethnic and gender labor market segmentation. Further, the findings will provide insights to further understand women and ethnic minority entrepreneurs' unique access to business development resources and the barriers they may encounter.

In addition, the national confidential dataset provides a unique opportunity in female and ethnic entrepreneurship studies. The large number of existing studies on ethnic and/or womenowned enterprises are "descriptive” (Chagnti and Greene 2002:129), focused on small business and low-skill economic activities (Barrett et al. 1996; Menzies et al. 2007). Meanwhile, by using Census data, many studies on ethnic entrepreneurship in the U.S. approximate "selfemployment" with business ownership. Such a treatment is obviously a compromise due to unavailable business data; however, it indeed introduces bias by picking up a large number of non-employer businesses (the truly self-employed) and leaving the real businesses out (Breggar 1996). The confidential data at the national scale thus provide a unique opportunity to examine a

full spectrum of ethnic minority and women-owned businesses. Furthermore, some previous studies using the Survey of Business Owners (SBO) data (either 1992 or 2002) may have delineated gender differences or ethnic differences in general (Fairlie and Robb 2008; Kepler and Shane 2007; Lowrey 2006); however, they do not focus on the nature of the segregated entrepreneurial process across ethnic and gender groups.

\section{Labor Market Segmentation, Entrepreneurship, and Business Performance (1) Ethnic businesses formation and ethnic labor market segmentation}


A preponderance of studies have shown that some ethnic groups (e.g., Koreans and Cubans) are more successful in establishing small businesses than others (e.g., Mexicans and African Americans) and members of the same ethnic group display different patterns of entrepreneurship in different places. A substantial number of hypotheses have been proposed to explain the substantial differences, including disparities in the possession of human capital, access to financial capital, cultural preferences, social networking, and structural factors (Fairlie and Robb 2008; Levent et al. 2009; Stiles and Galbraith 2004; see also a special issue by Journal of Ethnic and Migration Studies 2007). Although these different strands of literature do not directly discuss whether and why ethnic minority- owned businesses are particularly concentrated in specific industrial sectors, they correspond significantly well with those studies on ethnic labor market occupational or industrial segmentation.

For instance, social networking is regarded as an important factor that has lead to the concentration of particular ethnic groups in specific occupational or industrial sectors (Waldinger 1996; Wright and Ellis 2000). Consistently, a similar perspective argues that resources and social capital derived from belonging to a particular ethnic group and the use of associated networks, greatly enhance the start-up and continuing business success of an ethnic business by providing varying physical and intellectual ethnic resources such as labor, capital, supplier, and markets (Anthias and Cederberg 2009; Nakhaie et al. 2009; Wilson and Portes 1980; Zhou 1992). As a typical example, ethnic neighborhood or ethnic communities, such as Chinatown or Koreatown, have acted as business incubators in ethnic entrepreneurship (Hardwick 2003; Kaplan 1998; Lo et al. 2002; Teixeira et al. 2007). While many ethnic businesses owners obtain market information from similar sources among co-ethnic members and also turn to a common pool of 
labor and capital, unavoidably, many of them could end up operating in the same industrial sectors.

In contrast to the social capital perspective, labor market segmentation theories argue that racial discrimination, ethic barriers, and other structural factors may leave ethnic minority and new immigrants no choice but to find employment in an industry dominated by co-ethnic populations. Often, these sectors are featured as low-skilled, low pay, unstable and poor working conditions (Averitt 1968; Doeringer \& Piore 1971; Hudson 2007). Although with different forms, these theories correspond with social-structural perspectives on ethnic business formation. Specifically, the structuralism approach proposes that discrimination and marginalization force some ethnic minority groups and immigrants to become entrepreneurs (Light 2007; Raijman and Tienda 2000). Lacking open and equal career outlets due to "blocked opportunities" in the labor market, many ethnic minorities turn to business ownership (Aldrich and Waldinger 1990; Light and Bonacich 1988).

The above discussion indicates that the ethnic businesses could possibly be concentrated in particular industrial sectors, although the specific mechanisms could be different from that in ethnic segmentation in general wage labor markets. Indeed, Heibert (2002) has argued that there is a close correspondence between ethnic niches (where ethnic minority are concentrated in the labor market) and those where they become entrepreneurs. Indeed, research has demonstrated that ethnic businesses have trained many co-ethnic labor force who first works as employees but later moves to self-employment in an ethnic enclave before he/she expands to wider non-ethnic markets (Iyer and Shapiro 1999; Light 2007; Zhou and Cho 2010).

In addition to mechanisms, there is also contrasting view on the consequences of ethnic labor market segmentation and ethnic business ownership. With the social capital approach, 
concentration in co-ethnically concentrated sectors could provide ready-for-use, low-cost labor, suppliers, and critical protected markets (Wilson and Portes 1980; Portes and Jensen 1989; Zhou 1992); therefore, concentration may be a strategic positive tool for ethnic minority- owned business to start and grow. In contrast, the structuralism perspective emphasizes the disadvantages of concentrated ethnic business by arguing that an ethnic, spatial and sectoral enclosure from concentration may trap entrepreneurs in acutely constrained market potential (Assudani et al. 2009; Deakins et al. 2009; Kitching et al. 2009; Ley 2006). Barett et al. (2003: $113,114)$, while not concerned with segregation but on the issue of ethnic minority owned businesses in general, comment,

"We have long argued that co-ethnic customer dependency is a serious restriction on development and that real advancement hinges on breaking into mainstream unbounded markets in higher order sectors ... The implication may be that 'ethnic' firms can best succeed by becoming 'non-ethnic'.”

Indeed, there has been a great deal of literature debating about the economic returns of self-employment by immigrants or ethnic minorities (Heibert 2002; Li 1994, 1997, 2000; Light 1972, 2007; Wilson and Portes 1980). Unfortunately, the empirical results have never reached a consensus. As Nakhaie et al. (2009: 625-626) have described, “ ... the link between selfemployment and financial well-being among ethno-racial minorities has never been empirically established. In fact, extensive research in the US and limited studies in Canada have arrived at disparate results.” Such a disagreement calls for further examination on ethnic business performance, especially from the perspective of ethnic labor market segmentation or concentration.

\section{(2) Gender occupational segregation and entrepreneurship}


Feminist perspectives strongly argue that power relations in the household and the gendered nature of social life define job priorities differently for men and women (Reskin 1993; McDowell 1997, 2008). A considerable amount of literature has addressed that women frequently work in different types of jobs from men, highly concentrated in semi- or low-skilled, unstable sectors with poor working conditions and low pay. Explanations for gender labor market segregation include gender stereotype/discrimination, family role, limitation on women’s spatial mobility, and gender-based networking in the job searching process (England 1993; Hanson and Pratt 1995; Gilbert 1998; Wright et al. 2010).

Consistent with the observation of gender occupational segregation, researchers find that women-owned enterprises tend to be smaller in size, have lower profits, and are less likely to succeed (Budig 2006a, b; Cliff 1998; Lowrey 2006). Researchers also found that female-owned businesses are much less likely to be found in manufacturing and high-technology industries than are male-owned businesses (Brush et al. 2004; Kepler and Shane 2007). In understanding these differences, again, gender stereotypes, domestic responsibilities, and many other factors, such as risk-taking propensity and management style, have been identified in the previous literature (Blake and Hanson 2005; Minniti and Nardone 2007). In addition, lack of previous business experience, difficulty in obtaining financial support, and gender-based networking are significantly associated with female entrepreneurship (Bergen and Williams 1991; Hanson and Blake 2009; Moore 1990; Loscocco et al. 2009).

The above discussion on women-owned businesses did not consider race or ethnicity. Studies on ethnic minority- owned businesses are extremely rare. Tuner's study (2007) of smallscale enterprises in Makassar, Indonesia demonstrates that compared to gender and age, ethnicity stands out as a “central decision-making force” in labor recruitment, capital formation, product 
specialization, and networking. In the case of the Iranian women entrepreneurs in Los Angeles, however, networking through gender and ethnicity are both useful (Dallafar 1994). These women utilized their networks domestically and transnationally to start their businesses and seek to engage more of their social network to form new clients. While these studies provide interesting perspectives, they do not discuss whether ethnic minority women-owned businesses are likely to be engaged in particular industries.

Previous studies argue that women, especially visibly minority women, may face greater hardships in the labor market when compared with men and women from the majority group (Gabaccia 1991; Phizacklea 1983; Raijman and Semyonov 1997). In addition, many ethnic groups have their own cultural practices and social structures that could include a set of restrictive notions concerning the type of behavior that women might legitimately engage in and outside of the home, including owing a business (Geschewender 1992). Together, the racialized and gendered labor market process, the marginalization of being immigrants, and traditional cultural practices indicate a disadvantaged status of ethnic minority women business owners. At the same time, ethnic minority women could also take the advantages of both their ethnic and gender identity in developing their own business ventures. For example, women have played a critical role in the dominance of South Asians in the Dunkin' Donuts franchise industry in the U.S. Midwest (Rangaswamy 2007); also, women have been pioneers and backbone of domestic service as family businesses globally (Gratton 2007; Moya 2007). Light (2007) has argued that women employers increase demand for women employees, raising their earnings, and in the long could reduce women's inferiority. Under this perspective, we can expect that the concentration of women-owned businesses may provide a pathway toward upward mobility for some women entrepreneurs (Hanson 2009; Levant et al. 2009). 
Given the contrasting perspectives and mixed evidence from empirical studies, this current study uses a national survey in the U.S. to address the following two questions:

- How is business industrial concentration contingent on race, ethnicity, and gender?

- What are the consequences of industrial concentration on business performance?

\section{Data and Methodology}

\section{(1) Data}

The 2002 Survey of Business Owners (SBO), formerly known as the Survey of Minority- and Women-Owned Business Enterprises, is used in the current study. This survey was conducted by the U.S. Census Bureau. One of two census forms was mailed to a random sample of businesses selected from a list of all firms operating during 2002 with receipts of $\$ 1,000$ or more, except those in a very limited number of industries such as rail transportation, postal services, private households and public administration. The lists of all firms (or universe) are compiled from a combination of business tax returns and data collected on other U.S. economic census reports ${ }^{1}$.

The SBO is conducted on a company or firm basis rather than an establishment basis. A company or firm is a business consisting of one or more domestic establishments that the reporting firm specified under its ownership or control at the end of 2002. Approximately 81 percent of the 2.3 million businesses in the SBO sample responded to the survey. Business ownership is defined as having 51 percent or more of the stock or equity in the business and is categorized by gender, ethnicity (Hispanic versus non-Hispanic), and race (white, black, Asian,

\footnotetext{
${ }^{1}$ The U.S. Census Bureau obtains electronic files from the Internal Revenue Service (IRS) for all companies filing IRS Form 1040, Schedule C (individual proprietorship or self-employed person); 1065 (partnership); any one of the 1120 corporation tax forms; and 941 (Employer's Quarterly Federal Tax Return). The IRS provides certain identification, classification, and measurement data for businesses filing those forms. For most firms with paid employees, the Census Bureau also collected employment, payroll, receipts, and kind of business for each plant, store, or physical location during the 2002 Economic Census.
} 
etc. $)^{2}$. Male and female-equality owned businesses are not considered in the current study due to the focus on gender difference. Therefore, all the remaining businesses with ownership information are classified into eight groups by their owners: Non-Hispanic white male, nonHispanic white female, Hispanic male, Hispanic female, Non-Hispanic black male, non-Hispanic black female, Non-Hispanic Asian male, and non-Hispanic Asian female.

This dataset is unique in that, in addition to the ownership classified by gender and ethnicity, it provides the information on a firm's sales by receipts, payrolls, whether an employer or not, and employment size. It also provides statistics on owners' characteristics such as age and education, primary functions in the business, whether they are a family- and home-based businesses, their customer types, and financing for start-up and expansion. Different from public micro census data which only provide information on "self-employment," SBO 2002 is the only and the most recently available microdata on ethnic minority and women-owned businesses at the national scale in the U.S. Due to confidentiality and restrictive access to the data, only a handful of researchers have used a 1992 version (e.g., Fairlie and Robb 2008). An extremely limited number of studies have come out of the 2002 SBO data (e.g., Kepler and Shane 2007, Lowrey 2006) $)^{3}$.

\section{(2) Methodology}

The 3-digit NAICS is used to identify the industrial distribution for each ethnic and gender group. In order to measure their concentration across the industrial sectors, an odds ratio (OR) is used.

\footnotetext{
${ }^{2}$ In this study, for owner characteristics in multi-owner firms, the primary owner of the businesses is identified as the one with highest percent of the stock or equity in the business. If all the owners own exactly the same proportion, the primary owner will be identified randomly.

${ }^{3}$ These data are confidential, covered by Title 13 and subject to rigorous disclosure requirements. Their use requires prior approval by the Census Bureau and can only be accessed in secure facilities. The application requires a similar research proposal like this, but with a primary objective to help the Census Bureau to construct and improve data collection for census or surveys authorized under Title 13. The 2002 SBO is the most current confidential microdata that was made available to the author in 2009.
} 
An odd refers to the number of occurrences of a particular event divided by the number of nonevents. In the case of ethnic business concentration, the numerator of the OR is the ratio of businesses owned by group E in a sector i to businesses in all other sectors, t-I (i.e. Ei/Et-i). The denominator represents the same ratio for all businesses owned by other ethnic groups (i.e. Oi/Ot-i). Then OR is the ratio between these two odds. The values of odds ratio range from 0 to infinite. If $\mathrm{OR}<1$, it suggests that group $\mathrm{E}$ is less concentrated in sector i when compared to other groups. If $\mathrm{OR}>1$, it suggests that group $\mathrm{E}$ is more concentrated than other groups in sector $\mathrm{i}$. The higher the value of OR, the higher degree of concentration for group $\mathrm{E}$ in sector $\mathrm{i}$. We use a threshold value of 1.2 to identify the business concentrated sectors. That is, those businesses in an industrial sector with an odds ratio equal or larger than 1.2 will be regarded as niche business, or concentrated businesses ${ }^{4}$.

Business performance is measured from different dimensions: employment, sales (by receipt value $)^{5}$, and payrolls. Generally speaking, employer firms tend to have larger volumes of sales and payrolls. Therefore, employer firms and non-employer firms are examined separately in this study. Specifically, to gauge the relationship between employment and ethnic-gender concentration, a logistic regression will be first employed to evaluate the association between the probability of being an employer versus non-employer firm and being in ethnic-gender niches, while controlling for other businesses and the primary owner's characteristics. The basic form of the model is given by:

$$
\log [\mathrm{P} /(1-\mathrm{P})]=\mathrm{a}+\mathrm{bX}
$$

\footnotetext{
${ }^{4}$ In ethnic labor market segmentation and concentration studies, a representation index or location quotient has also been used in previous studies. The threshold values of the index also vary. For a more detailed discussion on different usages of different concentration indices and threshold values of odds ratio, please see Wang and Pandit (2007).

${ }^{5}$ Profits would be more ideal than sales when measuring the business performance. However, SBO2002 does not provide this information. So we will use sales to approximate the level of profit with an assumption that larger volumes of sales bring higher profits when other conditions are equal.
} 
where the dependent variable is the (log)odds of being an employer firm versus non-employer firm, $\mathrm{X}$ is the matrix of independent variables representing firm and the primary owner's characteristics, as well as whether the firm is an ethnic-gender niche firm. The independent variables are given in Table 1.

Then, for employer firms in particular, a multiple regression is used to examine the characteristics associated with a greater number of employees. The model is given by

$$
\mathrm{Y}=\mathrm{a}+\mathrm{bX}
$$

where the dependent variable is the number of employees in natural logarithm form and $\mathrm{X}$ is the matrix of independent variables representing the firm and the primary owner's characteristics, plus whether the firm is an ethnic-gender niche firm (Table 1).

In order to examine the relationship between sales and ethnic-gender concentration, a multiple regression like (2) is employed. For non-employer firms, the dependent variable (Y) is the annual sales (in natural logarithm form); for employer firms, both the total annual sales and annual sales per employee (the total annual sales divided by total number of employees) are examined to control for the influence of the firm size. The independent variables are the same as model (1) and (2).

The same multivariate regression as (2) is used for the investigation with payrolls. Since only employer-firms have payrolls, both the total annual payrolls and annual payrolls per employee (the total annual payrolls divided by total number of employees) are examined as the dependent variable. Again, the independent variables are the same as model (1) and (2).

\section{Findings}

(1) Characteristics of male-owned firms compared to female-owned firms 
Table 1 gives the characteristics of male-owned businesses compared with female-owned businesses across four ethnic groups. Measured by sales (receipt value), employment size, and total payrolls, male-owned businesses perform much better than their gender counterparts. For example, the average sales volume for white male-owned businesses is 3.7 times of that for white female-owned businesses. The differences across ethnic groups are striking as well. If measured by sales volume, white male businesses perform the best of all groups, followed by Asian and Hispanic male groups. Both black male and female-owned businesses rank the lowest. The similar pattern holds true for firm size (number of employees) and total payrolls.

\section{$<$ Table 1 is about here $>$}

Male-owned businesses are more likely than female-owned businesses to be an employer firm. While the gender difference within each ethnic group is consistent, Asian firms have a higher percentage of employer firms than all other groups. In contrast, women-owned businesses are more likely to have sole proprietorship than men-owned businesses, especially for black and Hispanic women groups.

For all ethnic groups, male-owned firms are established earlier. For example, the percentage of firms taken over or purchased before the 1980s among black male firms is 2.3 times that for black women-owned firms; the most recent acquisition (after 1997) for black male-owned businesses is 12 percent less than that for black women-owned businesses. In other words, most women-owned businesses are younger, or less likely to survive than their coethnic male-owned businesses.

Women-owned businesses across all ethnic groups are much more likely to be homebased than their gender counterparts. This is consistent with an expectation that women have more household responsibilities than men and are more "restricted,” voluntarily or involuntarily, 
at home. While home-based businesses tend to be smaller, they may need better connections to customers through family, friends, and neighborhood networking. Indeed, women are found more likely to use personal social networks through kinship and neighborhood in job-searching and looking for new markets (Blake and Hanson 2009; Dallarfur 1994). Meanwhile, black and white businesses are more likely to be home-based than Hispanic and Asian businesses, with blacks and Asians at two extreme ends. This could be due to the fact that most blacks and whites are native-born and may have a longer history of settlement in their neighborhoods. They could have more social networks than Asians or Hispanics that allow a home-based business to survive. Related to the immigrant background of Hispanic and Asian population, Hispanic and Asian businesses have obviously more connections with overseas markets, with a much higher percentage of export than the other two groups.

Consistent with higher percentage of home-base, women-owned businesses are more likely to start through family financing than their gender counterparts who are more likely to gain start-up finance through market investment including credit cards, banking investments, or other "formal" market channels. Also, women-owned businesses have a higher percentage of households as customers, while their gender counterparts have a larger market with customers who are businesses or with exporting products/services. However, male-owned businesses are more likely than women-owned businesses to be family owned. And the gender difference in family ownership for blacks and whites is bigger than that for Hispanic and Asian businesses.

The overall pattern is consistent with previous studies which show that women-owned businesses have lower performance levels if measured by sales and employment size (Budig 2006a, b; Cliff 1998; Lowrey 2006). Women are more likely to be dependent on family or kinship connections in financing options and markets. The gender difference holds true for all 
ethnic groups. Nevertheless, ethnicity still matters. Black businesses, especially those owned by black women, stay at the bottom if ranked by performances. The data do not allow the investigation of place of birth; however, although Asian businesses perform much better than Hispanic businesses, both groups demonstrate commonalities in their market base and possible transnational connections.

Table 2 gives some personal characteristics of the primary owner. Compared with male owners, women owners are much younger, especially with a much higher concentration at the age groups of 25-34. The age difference between men and women is relatively smaller at the age groups of 45-54. But when age gets even older, men are more likely to own a business than women, especially for those 65 years old or over. Women are not necessarily less educated than male owners, however. Female owners have higher concentration at the education level of above high school but not a bachelor's degree. Male owners have higher concentration at the education level either below a high school diploma or a bachelor’s degree or/and above.

<Table 2 about here $>$

In terms of primary functions in the business, for all other ethnic groups, men are more likely than women to deal with management and financial control in their businesses. While more women are involved part-time in their businesses than men, businesses are more likely to be primary income sources for men than for women. This is could be because that women may start their businesses not solely based on monetary purposes. Or, simply due to more family responsibilities, women owners are not as fully engaged in their businesses as men are.

\section{(2) Industrial concentration by gender and ethnicity}

Table 3 shows the industrial concentration of businesses across ethnic and gender groups, with a higher value of the odds ratios representing a higher degree of concentration in each industrial 
sector. In addition to primary industrial sectors, manufacturing, construction, utilities, and wholesale trade, white men-owned businesses are highly concentrated in Finance, Insurance, and Real Estate (FIRE), and management. In contrast, white women-owned businesses are highly concentrated in retail and social and personal services. White men-owned businesses do not share any common niche sectors with coethnic women owned businesses.

$<$ Table 3 about here $>$

Without sharing any common sectors with white male businesses, black male-owned businesses are highly concentrated in transportation and warehousing, administrative support, art, entertainment, recreation, and personal services. In addition to personal services, which is a common niche sector with black men, black women-owned businesses are highly concentrated in education services, health care and social assistance.

Construction is a niche sector for Hispanic male-owned businesses; other than that, they share common sectors with black male-owned businesses in all other sectors except for art, entertainment, and recreation. Hispanic female-owned businesses are mainly concentrated in administrative support, waste management, remediation services, health care and social assistance, and personal services.

Asian male- and female-owned businesses share common concentrations in retail, accommodation and food services, and personal services. In addition, males are more concentrated in wholesale, transportation and warehousing; and females are more concentrated in education services, health care and social assistance.

Overall, first, ethnicity stands out in that white male-owned businesses are the most different from all other ethnic and gender groups. Construction is the only concentrated sector that they share with others, that is, Hispanic males. All other ethnic minority groups share a 
common sector - personal services. Black males and Hispanic males are more alike with each other by concentrations in social and personal services. Second, the gender differences seem more prominent than ethnic differences. Some sectors are absolutely “male-dominated,” such as construction, transportation and warehousing; and some sectors are "female-dominated" such as education services, health care and social assistance. This general pattern is consistent with the occupational gender segregation pattern in general. All ethnic minority female-owned businesses are concentrated in the sectors where white females also have a higher concentration. The only difference is that white female's coverage is much wider than all other minority women groups possibly due to a greater number of businesses.

\section{(3) Concentration and Firm Size}

Table 4 gives the characteristics associated with the probability of being an employer firm. Across all ethnic and gender groups, businesses with sole proprietorship tend to have no employees. Compared to firms newly started or purchased, the older firms are more likely to be employers. Those firms started with financing through government-supported loans are more likely to hire employees; in contrast, firms with start-up finance through family channels are less likely to be employers, although it is not statistically significant for black female and Asians. Businesses with household customers and individual users are associated with a higher probability of being employer firms except for black female-owned ones. Likewise, businesses with customers who are also businesses or organizations are more likely to be employer firms except for black males, after other conditions are held constant.

\section{$<$ Table 4 about here $>$}

The effect from exporting goods or services shows a significant gender difference across ethnic groups. If controlling for other characteristics, male-owned businesses with overseas 
customers are less likely to be employer firms for all ethnic groups; however, white womenowned businesses with overseas customers are more likely to be employers, while the same characteristic is not significant for all other female groups.

At the owner level, older age groups are more likely to own employer firms than the youngest groups; however, the relationship is not linear. For example, the age group 35-44 for both white male and female owners is the most likely to be employers; however, for Hispanics, the 65 or over group is the most likely to be employers for both men and women; and, the most likely-to-be employer group is 45-54 for Asian men and 55-64 for Asian women. Compared to those without high-school diplomas, owners with a high-school diploma but not a bachelor's degree are less likely to hire workers; but, those with a bachelor's degree and above are more likely to be employers. Those owners with the primary function of production or day-to-day operation management are not likely to hire employees; however, employer firms' owners are more likely to have financial control with the authority to sing loans, leases, and contracts. In terms of working hours, owners in employer firms obviously work longer.

For all employer firms, a greater number of employees is associated with the characteristics similar to the patterns discussed above (results not shown but available upon request). That is, a greater number of employees is positively associated with non-sole proprietorship, earlier acquisition, start-up funds through government-supported programs, having customers who are also businesses or organization, having owners with a primary function not as production or day-to-day operations, but with financial control of the business. Meanwhile, business owners who have at least a bachelor's degree and work full time have a greater number of employees than those who do not have similar characteristics. The major differences lie in customer type and business owners’ age. Specifically, among employer firms, 
those with household and individual users tend to have fewer employees. While overseas connections are associated with non-employers for male groups, overseas markets are associated with more employees for both white male and female owned employer firms. Although older age is a significant predictor of being an employer firms, for the employer firms, age does not make significant differences in the number of employees except for white men.

For all businesses, after considering all other firm- and owner-level characteristics, businesses in their concentrated industrial sectors are still more likely to be employers compared to non-concentrated businesses (Table 4). This positive relationship holds true for all groups, although it tends to be stronger for male-owned businesses (when compared with coethnic women). For example, when holding other conditions constant, for white men, the likelihood of being an employer firm for a business in concentrated sectors increases twice when compared with a business in non-concentrated sectors. The likelihood increases 87 percent for white females when comparing concentrated businesses with non-concentrated businesses. And the increase is 91 percent for black male, 62 percent for black female, 1.1 times for Hispanic male, 64 percent for Hispanic female, and twice for both Asian male- and female- owned businesses.

Likewise, among the employer firms, concentrated businesses are most often associated with a greater number of employees than those non-concentrated businesses. The differences between male and female owned business within the same ethnic group are not significant. In other words, within employer firms, the concentrated businesses, regardless of gender and ethnicity, tend to hire more than those in non-concentrated sectors if holding other characteristics constant; furthermore, the positive relationship between concentration and number of employees does not make much difference between male and female owned businesses.

\section{(4) Concentration and Sales Volume}


For non-employer firms, Table 5 gives the characteristics associated with higher volume of sales by receipt values. Lower volume sales are associated with sole-proprietorship firms whose startup funds came through families and where the owner primarily functions as production or dayto- day management and has shorter working hours; meanwhile, higher volume of sales are associated with older businesses, businesses with customers who are also businesses or organizations, and owners who are older or have financial controls.

While the oldest firms are most likely to be employers, those businesses started or taken over during the 1980s are the most likely to make higher profits for non-employers, for most ethnic and gender groups. Although start-up capital through government-supported programs are highly associated with being employer firms, for non-employer firms, the positive effect on sales only exists for white men, white women, and black men-owned businesses. Different from household or individual customers’ positive effect on the probability of being employer firms, this type of customer predicts lower sales volume for non-employer firms. While linkage with overseas customers is often associated with non-employer firms, especially for men, it does bring higher sales for most groups. The insignificance of overseas connections for black-owned businesses could reflect that a very small proportion of them have exported goods or services. At the owner level, although older age is associated with higher volume of sales, higher level of education is not.

Earlier discussion suggests that women-owned businesses are highly concentrated in some "female-type" of industrial sectors, such as education services, healthcare services, and personal services. The concentration patterns also differ by ethnicity. We expect that those concentrated businesses, especially women-owned businesses may fare worse than those in nonconcentrated sectors. Out of expectation, however, after considering other firm and owner level 
characteristics, non-employer firms in niche sectors have higher sales volumes than those in nonniche sectors, for all ethnic and gender groups, although the niche advantage for women-owned businesses is smaller compared to male owned businesses in niches. If we hypothesize that higher sales predict higher profits, findings here suggest that niche businesses are not actually disadvantaged in economic returns when compared to non-niche businesses.

\section{$<$ Table 5 about here $>$}

For employer firms, characteristics associated with higher sales are very similarly to nonemployer firms without controlling for the size of employment (the results are not shown here but available upon request). Different from non-employer firms, however, for employer firms, earlier establishment or acquisition is significantly associated with higher sales when compared with younger businesses; owners' age makes a difference only for male-owned businesses; and owners with a higher education tend to have higher sales. After considering other characteristics, similar to non-employer firms, the concentrated firms tend to earn more than non-concentrated firms in terms of total sales. However, for Hispanic and Asian female- owned employer firms, the coefficient of concentration is not significant. In other words, concentrated firms do not earn more than non-concentrated firms for these two groups if measured by total sales.

More differences between the employer firms and non-employer firms emerge if considering the sales by employment size. Table 6 gives the regression results for sales per employee (the business's total sales divided by the total number of employees). While start-up capital through government-supported programs is associated with higher total sales for both employer and non-employer firms, employer firms' sales per employee tend to be lower for those businesses with start-up financing through government programs. For non-employer firms, the older the owners' age, the higher level of total sales; however, the positive association 
between owner's older age and higher sales per employee for employer firms only exists for white male-owned businesses, not for any other gender or ethnic group.

$<$ Table 6 about here $>$

Different from the positive concentration effects on total sales for non-employers across ethnicity and gender, being in niche sectors will increase the sales per employee for male-owned businesses only, when holding other conditions constant. For women-owned businesses, concentration will significantly decrease sales per employee for white, Hispanic and Asian female groups. This pattern suggests that women owned businesses in their concentrated sectors are hiring more workers than those in non-niches; however, if considering the number of employees, these niche businesses do not have higher economic returns than non-niche employer firms. This pattern is also different from non-employer firms who enjoy higher sales volume by concentrating in industrial niche sectors.

\section{(5) Concentration and Payroll}

The characteristics associated with higher payrolls are very similar to that associated with greater employment size (results are not shown but available upon request). For instance, a greater size of employment and higher payrolls are positively associated with non-sole proprietorship, earlier acquisition, start-up financing through government-supported programs, having customers who are also businesses or organization, exporting goods or service, having owners with a higher education, and a primary function as financial control of the business, but not involved production or day-to-day operation management.

While owner's age is significant only for white male-owned businesses in terms of total employment size, age makes a significant difference in total payroll for those businesses owned by white men and women, Hispanic men, and Asian men. A major difference comes from the 
industrial concentration effect. While concentration is positively related to greater employment size for employer firms and total payroll for most groups, the concentrated businesses do not have advantages in total payroll for businesses owned by black females, Hispanic females, and Asian males, after controlling for other characteristics in the model. Further, the size of employment is considered, the niche effect for the payroll per employee is totally opposite (results are not shown here but available upon request). That is, being in niche sectors will significantly decrease the payroll per employee across all ethnic and gender groups. The decrease effects are particularly higher for most women-owned business groups.

\section{Discussion and Conclusions}

Built upon the literature of labor market segregation and segmentation, this study draws a national profile on businesses industrial concentration along the divide of gender and race/ethnicity. Due to data scarcity, very few studies have provided similar research at such a large scale. Results from national business surveys in the U.S. show that men- and womenowned businesses tend to concentrate at different sectors. Some sectors are absolutely "maledominated," such as construction, transportation and warehousing; and some sectors are "femaledominated," such as education services, health care and social assistance. This concentration pattern is consistent with what has been found in gender occupational segregation in general.

Although gender difference in business concentration patterns is more prominent, ethnicity still makes a difference. Specifically, white male-owned businesses are the most different from all other ethnic and gender groups. Black and Hispanic male-owned businesses are more alike with each other. Asian male- and female-owned businesses share more common sectors than most other ethnic groups. Although the number of sectors concentrated by ethnic minority female-owned businesses is smaller than that of white female-owned businesses, the 
total number of ethnic minority women-owned businesses engaged in these sectors is much higher. In other words, ethnic minority female- owned businesses are highly concentrated in a very limited number of industrial sectors.

Overall, the characteristics associated with higher sales, larger employment, and higher payroll at both business and owner's level share many common features across all gender and ethnic groups: non-sole proprietorship, earlier acquisition, having customers who are also businesses or organization, having owners with primary functions of financial control of the business and longer working hours.

The government-supported programs in start-up financing are noteworthy. Those firms started with financing through government-supported loans are more likely to be employers; however, for non-employer firms, the positive effects on total sales only exist for white men, white women, and black men-owned businesses. For employer-firms, if we consider the size of employees, employer firms’ sales per employee tend to be lower for those businesses with startup financing through government programs. These programs are positively related with higher total payrolls for employer firms, but negatively related with payroll per employee for businesses owned by white men and women, black women, and Asian men. It is reasonable to conclude that these programs could have some positive effects in generating more jobs, although such positive effects are ethnic and gender specific. At the same time, such programs may not be an efficient tool in generating more sales/profits for most employer firms, if considering firm size.

The owner's primary functions in their businesses suggest significant disadvantages of women owners. The pattern is clear that financial control function is significantly associated with larger size, higher sales, and higher payrolls, for both employer and non-employer firms. However, compared to male owners who are more likely to have financial control of their 
businesses, female owners' primary functions are highly involved with production or day-to-day operation, but lack financial control of the business. That is, not only do women have more difficulty in securing funds to start their businesses, but such a deficiency has long-lasting effects on their business growth.

The effect of a businesses' industrial concentration by ethnicity and gender is mixed. In general, for non-employer firms, it is indeed related to better economic returns if measured by sales; but, the positive effect is contingent on gender. For employer firms, concentrated firms tend to be larger, which also predicts higher total sales and total payroll. However, such an "aggregated" effect is mainly significant for most male groups, not female; in particular, if the size of employment is considered, the disadvantages of concentration for women-owned firms emerge. Specifically, the following three patterns stand out:

First, although male- and female- owned businesses tend to concentrate in different industrial sectors, after considering other firm and owner characteristics, businesses in niche sectors are still more likely to be employers compared to non-niche businesses. This positive relationship holds true for all groups, however, it tends to be stronger for male- owned businesses (when compared with coethnic female-owed businesses). Likewise, for employer firms, the concentrated businesses, regardless gender and ethnicity, tend to hire more than those in non-concentrated sectors if holding other characteristics constant.

Second, while ethnic minority women- owned businesses are highly concentrated in those sectors with easy-entry at the lower labor market level, people would expect that these “segregated” businesses fare worse. However, non-employer firms in niche sectors have higher sales volumes than those in non-niches, for all ethnic and gender groups. But, a distinctive gender difference shows up: for non-employer firms, the positive relationship between 
concentration and total sales is much weaker for women-owned businesses. For employer firms, women-owned businesses in their highly concentrated niches do not have advantages in total sales. Furthermore, if we consider the size of the employees, while concentration could increase the sales per employee for male- owned businesses, it will significantly decrease sales per employee for most women- owned businesses.

Third, concentration is positively related with total payroll for white men and women, black men, Hispanic men, and Asian women. If the size of employment is considered, however, being in niche sectors will significantly decrease the payroll per employee across all ethnic and gender groups. The decrease effects are particularly higher for most women groups.

The overall pattern indicates that, for those really small businesses, especially those selfemployed, regardless of ethnicity and gender, they may not necessarily end up in ethnic-gender segregated sectors; even if they do, they may find some special niches through social capital which help them not necessarily fare worse than non-concentrated counterparts. Many maleowned businesses in their niches, employer firms or not, seem to enjoy better economic returns. Women employer firms represent a "paradox": The highly concentrated businesses are actually providing many jobs; but, those sectors obviously pay less and have marginal profits, especially when considering the size of the firms. Needless to say, we have to consider how to measure business “performance.” Beyond economic return, other aspects such as lifestyle change is particularly meaningful for women. Researchers have argued that ethnic businesses or women owned businesses have provided both economic and non-economic benefits to their own, other women, and their communities (Hanson 2009; Levant et al. 2009; Light 2007; Zhou and Cho 2010). Future research needs to explore different ways to measure the impacts of business concentration or segregation. Another necessary step would be to examine how different 
racial/ethnic and gender groups are concentrated into different sectors in their entrepreneurial

process, and how such a process is different from or similar to wage labor market segmentation.

In addition, this is a nationally aggregated study. How different ethnic and gender groups

perform and engage in different business activities is highly dependent on local socioeconomic

and institutional environments. Based on the national general profile, more localized and

contextualized research on this aspect is warranted to understand both the process and impacts of

business segregation by race/ethnicity and gender.

\section{References}

Aldrich, H. and Waldinger, R. (1990) 'Ethnicity and entrepreneurship’, Annual Review of Sociology, 16: 111-135.

Anthias, F. and Cederberg, M. (2009) 'Using ethnic bonds in self-employment and the issue of social capital', Journal of Ethnic and Migration Studies, 35(6): 901-917.

Appold, S. J. and Kasard, J.D. (2004) 'Building community through entrepreneurship: Lessons from Vietnam and the United States', in Butler, J and Kozmetsky, G. (eds) Immigrant and Minority Entrepreneurship: Building American Communities. Westport, CT: Greenwood Press, 61-84.

Assudani, R. (2009) 'Ethnic entrepreneurship: The distinct role of ties', Journal of Small Business and Entrepreneurship, 22(2): 197-206.

Averitt, R.T. (1968) The Dual Economy. New York: Norton.

Barrett, G.A., Jones, T.P. and McEvoy, D. (1996) 'Ethnic minority business: Theoretical discourse in Britain and North America', Urban Studies, 33: 783-809.

Barrett, G.A., Jones, T.P. and McEvoy, D. (2003) 'United Kingdom: Severely constrained entrepreneurialism', in Kloosterman, R. and Rath, J. (eds) Immigrant Entrepreneurs: Venturing abroad in the Age of Globalization. Berg Publishers, 101-122.

Bates, T. (2006) 'The urban development potential of black-owned businesses', Journal of the American Planning Association, 72(2): 227-237.

Bergen, D. and Williams, J. (1992) 'Sex stereotypes in the United States revisited: 1972-1988', Sex Roles, 24(7-8): 413-423.

Blake, M.K. and Hanson, S. (2005) 'Rethinking innovation: Context and gender', Environment and Planning A, 37: 681-701.

Bregger, J. (1996) 'Measuring self-employment in the United States', Monthly Labor Review, 119(1-2): 3-9.

Budig, M. J. (2006a) 'Intersections on the road to self-employment: Gender, family and occupational class', Social Forces, 84: 2223-2239.

Budig, M. J. (2006b) ‘Gender, self-employment, and earnings’, Gender \& Society, 20(6): 725753. 
Chaganti, R. and Greene, P. (2002) 'Who are ethnic entrepreneurs? A study of entrepreneurs ethnic involvement and business characteristics', Journal of Small Business Management, 40(2): 126-143.

Cliff, J. E. (1998) 'Does one size fit all? Exploring relationships between attitudes towards growth, gender, and business size’, Journal of Business Venturing, 13(6): 523-542.

Dallalfar, A. (1994) 'Iranian women as immigrant entrepreneurs', Gender \& Society, 8(4):541561.

Deakins, D., Smallbone, D., Ishaq, M., Whittam, G. and Wyper, J. (2009) 'Minority ethnic enterprise in Scotland’, Journal of Ethnic and Migration Studies, 35(2): 309-330.

Doeringer, P. B. and Piore, M. J. (1971) Internal Labor Markets and Manpower Analysis. Lexington, MA: D.C. Heath and Company.

England, P. (1981). 'Assessing trends in occupational sex-segregation, 1900-1976', in Berg, I. (ed.) Sociology Perspectives on Labor Market. New York: Academic Press.

England, P. (1993) Theory on Gender/Feminism on Theory. New York: Aldine De Gruyter.

Farley, R., and Allen, W.R. (1987) 'The color line and the quality of life in America', New York: Russell Sage.

Fairlie, R.W. and Robb, A.M. (2008) Race and Entrepreneurial Success: Black-, Asian-, and White-owned Businesses in the United States. The MIT Press.

Furuseth, O. (2009) 'A new rural North Carolina: Latino place-making and community engagement', in Halseth, G., Markey, S. and Bruce, D. (eds) The Next Rural Economies: Constructing Rural Place in Global Economies. CABI Publishing, Wallingford, United Kingdom: 45-58.

Gabaccia, D. (1991) 'Immigrant women: Nowhere at home’, Journal of American Ethnic History 10(4): 61-87.

Geschwender, J. A. (1992) 'Ethnicity and the social construction of gender in the Chinese diaspora', Gender and Society, 6(3): 480-507.

Gilbert, M. (1998) 'Race, space and power: The survival strategies of working poor women', Annals of the Association of American Geographers, 88(4): 595-621.

Gratton, B. (2007) 'Ecuadorians in the United States and Spain: History, gender and niche formation', Journal of Ethnic and Migration Studies, 33(4): 581 - 599.

Hanson, S. (2009) 'Changing places through women's entrepreneurship', Economic Geography, 85(3): 245-267.

Hanson, S. and Blake, M.K. (2009) ‘Gender and entrepreneurial networks’, Regional Studies, 43(1): 135-149.

Hardwick, S.W. (2003) 'Migration, embedded networks and social capital: Toward theorising North American ethnic geography', International Journal of Population Geography, 9: 163-179.

Hiebert, D. 'Economic associations of immigrant self-employment in Canada', International Journal of Entrepreneurial Behavior and Research, 8: 127-140.

Hudson, K. (2007). 'The new labor market segmentation: Labor market dualism in the new economy’, Social Science Research, 27: 286-312.

Iyer, G.R. and Shapiro, J.M. (1999) 'Ethnic entrepreneurial and marketing systems: Implications for the global economy’, Journal of International Marketing, 7(4): 83-110.

Journal of Ethnic and Migration Studies, 2007. A special issue, 33(4).

Kaplan, D. (1998) 'The spatial structure of urban ethnic economies', Urban Geography, 19(6): 489-501. 
Kaplan, D. and Li, W. (2006) Landscapes of the Ethnic Economy. Rowman \& Littlefield Publishers.

Kepler, E. and Shane S. (2007) Are Male and Female Entrepreneurs Really That Different? Office of Advocacy, Small business Administration.

Kitching, J., Smallbone, D. and Athayde. R. (2009) 'Ethnic diasporas and business competitiveness: Minority-owned enterprises in London’, Journal of Ethnic and Migration Studies, 35(4): 689-705.

Ley, D. (2006) 'Explaining variations in business performance among immigrant entrepreneurs in Canada', Journal of Ethnic and Migration Studies, 32 (5): 743 - 764.

Levent, T.B., Nijkamp, P. and Sahin, M. (2009) 'New orientations in ethnic entrepreneurship: Motivation, goals and strategies of new generation ethnic entrepreneurs', International Journal of Foresight and Innovation Policy, 5(1-3): 83-112.

Li, P.S. (1994) 'Self-employment and its economic return for visible minorities in Canada', New Approaches to Employee Management, 2: 181-199.

Li, P.S. 1997. Self-employment among visible minority immigrants, white immigrants, and native-born persons in secondary and tertiary industries of Canada." Canadian Journal of Regional Science 20: 103-118.

Li, P.S. (2000) 'Economic returns of immigrants' self-employment', The Canadian Journal of Sociology, 25(1): 1-34.

Lieberson, S., and Water, M.C. (1990) From Many Strands: Ethnic and racial Groups in Contemporary American. New York: Russell Sage.

Light, I. (1972) Ethnic enterprise in America: Business and welfare among Chinese, Japanese, and Blacks. Berkeley, CA: University of California Press.

Light, I. (2007) 'Women's economic niches and earnings inferiority: The view from the ethnic economy', Journal of Ethnic and Migration Studies, 33(4): 541-557.

Light, I. and Bonacich, E. (1988) Immigrant Entrepreneurs: Koreans in Los Angeles, 1965-1982. Berkeley: University of California Press.

Lo, L., Teixeira, C. and Truelove, M. (2002) Cultural resources, ethnic strategies and immigrant entrepreneurship: A comparative study of five ethnic groups in the Toronto CMA. Working paper No. 21. Toronto: Centre of Excellence for Research on Immigration and Settlement.

Loscocco, K., Monnat, S. M., Moore, G. and Lauber, K.B. (2009) 'Enterprising women: A comparison of women's and men's small business networks', Gender \& Society, 23(3): 388411.

Lowrey, Y. (2006) Women in Business: A Demographic Review of Women's Business Ownership. Office of Advocacy, U.S. Small Business Administration.

Mayer, H. (2008) 'Segmentation and segregation patterns of women-owned high-tech firms in four metropolitan regions in the United States', Regional Studies, 42(10): 1357-1383.

McDowell, L. (1997) Capital Culture: Gender at Work in the City. Oxford: Blackwell.

McDowell, L. (2008) 'Thinking through work: Complex inequalities, constructions of difference and trans-national migrants’, Progress in Human Geography, 32(4): 491-507.

Menzies, T., Filion, L., Brenner, G. and Elgie, S. (2007) 'Measuring ethnic community involvement: Development and initial testing of an index', Journal of Small Business Management, 45(2): 267-282.

Minniti, M. and Nardone, C. (2007) 'Being in someone else's shoes: the role of gender in nascent entrepreneurship’, Small Business Economics, 28(2-3): 223-238.

Moore, G. (1990) 'Structural Determinants of Men's and Women's Personal Networks', 
American Sociological Review, 55(5): 726-735.

Moya, J. (2007) Domestic service in a global perspective: Gender, migration and ethnic niches. Journal of Ethnic and Migration Studies 33(4) 559-579.

Rangaswamy, P. (2007) 'South Asians in Dunkin' Donuts: Niche Development in the Franchise Industry', Journal of Ethnic and Migration Studies, 33(4): 671-686.

Nakhaie, R., Lin, X., and Guan, J. (2009) 'Social capital and the myth of minority selfemployment: Evidence from Canada’, Journal of Ethnic and Migration Studies, 35(4): 625644.

Phizacklea, A. (1983) One Way Ticket: Migration and Female Labour. Boston: Routledge \& Kegan Paul.

Portes, A. and Jensen, L. (1989) 'The enclave and the entrants: patterns of ethnic enterprise in Miami before and after Mariel’, American Sociological Review, 54(6): 929-949.

Raijman, R. and Semyonov, M. (1997) 'Gender, ethnicity, and immigration: double disadvantage and triple disadvantage among recent immigrant women in the Israeli labor market', Gender and Society, 11(1): 108-125.

Raijman, R. and Tienda, M. (2000) 'Immigrants pathway to business ownership: A comparative ethnic perspective’, International Migration Review, 34(3): 682-706.

Reskin, B.F. (1993) 'Sex segregation in the workplace', Annual Review of Sociology, 19: 241270.

Schrover, M., van der Leun, J. and Quispel, C. (2007) 'Niches, labour market segregation, ethnicity and gender', Journal of Ethnic and Migration Studies, 33(4): 529-540.

Stiles, C. H., and Galbraith, C.S. (2004) Ethnic Entrepreneurship: Structure and Process. Oxford, UK: Elsevier Ltd.

Teixeira, C. (2001) 'Community resources and opportunities in ethnic economies: A case study of portuguese and black entrepreneurs in Toronto’, Urban Studies, 38(11): 2055 - 2078.

Teixeira, C, Lo, L. and Truelove, M. (2007) 'Immigrant entrepreneurship, institutional discrimination, and implications for public policy: a case study in Toronto', Environment and Planning C: Government and Policy, 25(2): 176 - 193.

Waldinger, R. (1996) Still The Promised City. Harvard University Press.

Wang, Q. and Pandit, K. (2007) 'Measuring ethnic labour market concentration and segmentation', Journal of Ethnic and Migration Studies, 33(8): 1227 -1252.

Wilson, K.L. and Portes, A. (1980) 'Immigrant enclaves: An analysis of the labor market experiences of Cubans in Miami', American Journal of Sociology, 86: 295-319.

Wright , R. and Ellis, M. (2000) 'The ethnic and gender division of labor compared among immigrants to Los Angeles', International Journal of Urban and Regional Research, 24(3): 583-601.

Wright, R., Ellis, M. and Parks, V. (2010) Immigrant niches and the intrametropolitan spatial division of labour. Journal of Ethnic and Migration Studies 36: 1033-1059.

Zhou, M. (1992) Chinatown: The Socioeconomic Potential of an Urban Enclave. Philadelphia: Temple University Press.

Zhou, M. and Cho, M. (2010) 'Noneconomic effects of ethnic entrepreneurship: Evidence from Chinatown and Koreatown in Los Angeles, USA', Thunderbird International Business Review, 52 (2). 
Table 1 Characteristics of women-owned businesses compared with men-owned businesses

\begin{tabular}{|c|c|c|c|c|c|c|c|c|}
\hline & \multicolumn{2}{|l|}{ Asian } & \multicolumn{2}{|l|}{ Black } & \multicolumn{2}{|l|}{ Hispanic } & \multicolumn{2}{|l|}{ White } \\
\hline Variable & Male & Female & Male & Female & Male & Female & Male & Female \\
\hline & & & & & & & & \\
\hline & 546.446 & 245.144 & 242.746 & & 368.518 & 149.220 & 856.790 & 233.500 \\
\hline receipt & 2 & 4 & 7 & 76.0916 & 4 & 8 & 3 & 1 \\
\hline size & 3.2991 & 1.9404 & 2.0878 & 0.9358 & 2.4016 & 1.3464 & 5.0805 & 2.0117 \\
\hline Payroll & 92.2913 & 45.1586 & 52.6611 & 19.4692 & 64.6235 & 30.5657 & $\begin{array}{r}160.655 \\
1\end{array}$ & 49.5657 \\
\hline $\begin{array}{l}\text { Employer } \\
\%\end{array}$ & 42.27 & 30.95 & 19.32 & 12.36 & 27.58 & 20.54 & 36.8 & 23.34 \\
\hline sole & 47.94 & 59.23 & 61.95 & 68.2 & 59.96 & 65.7 & 49.29 & 61.21 \\
\hline $\begin{array}{l}\text { Acquire } \\
\text { before } 80\end{array}$ & 6.24 & 3.26 & 8.57 & 3.73 & 7.39 & 4.24 & 16.05 & 7.85 \\
\hline
\end{tabular}




\begin{tabular}{|l|r|r|r|r|r|r|r|r|}
\hline $\begin{array}{l}\text { Acquire } \\
1980-90\end{array}$ & 14.42 & 10.94 & 14.32 & 9.3 & 14.11 & 10.29 & 21.22 & 16.3 \\
\hline $\begin{array}{l}\text { Acquire } \\
1990-96\end{array}$ & 23.02 & 20.73 & 21.37 & 19.14 & 21.59 & 19.12 & 23.37 & 23.78 \\
\hline $\begin{array}{l}\text { Acquire } \\
\text { after1997 }\end{array}$ & 56.32 & 65.07 & 55.73 & 67.83 & 56.92 & 66.34 & 39.36 & 52.07 \\
\hline homebase & 27.01 & 31.96 & 55.11 & 64.45 & 46.38 & 52.2 & 47.14 & 59.01 \\
\hline $\begin{array}{l}\text { Family } \\
\text { owned }\end{array}$ & 18.47 & 17.12 & 14.3 & 10.6 & 17.72 & 16.19 & 19.2 & 16.21 \\
\hline $\begin{array}{l}\text { Govern } \\
\text { loan }\end{array}$ & 2.39 & 1.99 & 2.33 & 2.15 & 1.74 & 1.72 & 1.99 & 1.8 \\
\hline $\begin{array}{l}\text { Family } \\
\text { funds }\end{array}$ & 87.33 & 88.89 & 87.56 & 88.65 & 87.42 & 88.45 & 85.46 & 88.05 \\
\hline $\begin{array}{l}\text { Market } \\
\text { invest }\end{array}$ & 28.64 & 24.58 & 27.87 & 25.05 & 26.05 & 24.44 & 31.52 & 27.08 \\
\hline $\begin{array}{l}\text { Household } \\
\text { customer }\end{array}$ & 51.04 & 56.82 & 55.11 & 61.64 & 51.83 & 60.93 & 54.19 & 64.84 \\
\hline $\begin{array}{l}\text { Business } \\
\text { customer }\end{array}$ & 28.78 & 22.83 & 30.51 & 19.26 & 32.7 & 21.31 & 42.92 & 29.02 \\
\hline Exporting & 3.89 & 3.37 & 1.97 & 1.23 & 3.81 & 2.4 & 1.59 & 0.82 \\
\hline $\begin{array}{l}\text { Exumber } \\
\text { Number|| }\end{array}$ & 224512 & 101380 & 121151 & 86575 & 236619 & 100439 & 4671533 & 1778405 \\
\hline
\end{tabular}

Table 2 Characteristics of the primary owner

\begin{tabular}{|c|c|c|c|c|c|c|c|c|}
\hline & AM & AF & BM & BF & $\mathrm{HM}$ & $\mathrm{HF}$ & WM & WF \\
\hline Variable & Mean & Mean & Mean & Mean & Mean & Mean & Mean & Mean \\
\hline$<25 y r s$ & 2.7 & 3.94 & 2 & 3.65 & 3.9 & 5.51 & 2.44 & 3.03 \\
\hline $25-34$ & 15.89 & 19.11 & 13.82 & 18.7 & 18.53 & 21.53 & 10.94 & 14.89 \\
\hline $35-44$ & 28.51 & 30.12 & 26.55 & 28.32 & 31.62 & 30.76 & 22.89 & 26.09 \\
\hline $45-54$ & 29.55 & 29.05 & 29.61 & 26.98 & 26.06 & 25.39 & 29.51 & 28.3 \\
\hline $55-64$ & 17.66 & 13.52 & 18.11 & 15.84 & 14.12 & 12.71 & 21.63 & 18.92 \\
\hline$>=65$ & 5.69 & 4.26 & 9.91 & 6.51 & 5.77 & 4.09 & 12.59 & 8.77 \\
\hline $\begin{array}{l}<=\text { high } \\
\text { School }\end{array}$ & 24.5 & 28.4 & 30.4 & 27.23 & 46.8 & 43.6 & 27.15 & 23.93 \\
\hline $\begin{array}{l}\text { Hschool- } \\
\text { bachelor }\end{array}$ & 20.77 & 23.93 & 37 & 41.14 & 28.97 & 33.86 & 29.22 & 36.34 \\
\hline
\end{tabular}




\begin{tabular}{|l|r|r|r|r|r|r|r|r|}
\hline >=bachelor & 54.73 & 47.67 & 32.6 & 31.63 & 24.22 & 22.53 & 43.64 & 39.74 \\
\hline produce & 58.09 & 60.69 & 55.9 & 49.7 & 59.89 & 54.31 & 61.44 & 59.72 \\
\hline manage & 51.43 & 46.69 & 51.55 & 46.96 & 46.96 & 40.44 & 58.93 & 52.43 \\
\hline finance & 32.97 & 28.76 & 29.04 & 22.4 & 27.55 & 21.83 & 45.24 & 35.33 \\
\hline Other & 14 & 16.06 & 17.16 & 23.62 & 16.38 & 24.41 & 11.2 & 16.93 \\
\hline $\begin{array}{l}\text { Primary } \\
\text { income }\end{array}$ & 66.09 & 61.06 & 50.21 & 47.84 & 67.46 & 58.54 & 58.86 & 47.83 \\
\hline $\begin{array}{l}<40 \text { work } \\
\text { hours }\end{array}$ & 41.46 & 53.09 & 52.32 & 60.13 & 41.73 & 61.13 & 46.88 & 65.68 \\
\hline Number & 383052 & 198107 & 256538 & 231397 & 473379 & 263864 & 7889229 & 3680075 \\
\hline
\end{tabular}

Table 3 Industrial concentration of businesses (only Odds ratio $>=1.2$ shown)

\begin{tabular}{|c|c|c|c|c|c|c|c|c|}
\hline \multirow[t]{2}{*}{ Sector (by NAICS 2-Digit codes) } & \multicolumn{2}{|c|}{ white } & \multicolumn{2}{|c|}{ black } & \multicolumn{2}{|c|}{ Hispanic } & \multicolumn{2}{|l|}{ Asian } \\
\hline & male & female & male & female & male & female & male & female \\
\hline Agriculture, Fishing, Forestry, Hunting & 3.1 & 0 & 0 & 0 & 0 & 0 & 0 & 0 \\
\hline Mining & 3.4 & 0 & 0 & 0 & 0 & 0 & 0 & 0 \\
\hline Utilities & 2.6 & 0 & 0 & 0 & 0 & 0 & 0 & $\mathrm{D}$ \\
\hline Construction & 3.8 & 0 & 0 & 0 & 1.8 & 0 & 0 & 0 \\
\hline manufacturing & 1.8 & 0 & 0 & 0 & 0 & 0 & 0 & 0 \\
\hline whole sale trade & 1.7 & 0 & 0 & 0 & 0 & 0 & 1.7 & 0 \\
\hline retail trade & 0 & 1.9 & 0 & 0 & 0 & 0 & 1.3 & 1.2 \\
\hline Transportation and Warehousing & 0 & 0 & 4.1 & 0 & 3.2 & 0 & 1.7 & 0 \\
\hline Information & 0 & 0 & 0 & 0 & 0 & 0 & 0 & 0 \\
\hline Finance and Insurance & 1.9 & 0 & 0 & 0 & 0 & 0 & 0 & 0 \\
\hline Real Estate and Rental and Leasing & 1.4 & 0 & 0 & 0 & 0 & 0 & 0 & 0 \\
\hline $\begin{array}{l}\text { Professional, Scientific, } \\
\text { and Technical Services }\end{array}$ & 0 & 0 & 0 & 0 & 0 & 0 & 0 & 0 \\
\hline Management & 3.8 & 0 & 0 & $\mathrm{D}$ & 0 & $\mathrm{D}$ & 0 & 0 \\
\hline $\begin{array}{l}\text { Administrative Support; Waste } \\
\text { Management \& Remediation Services }\end{array}$ & 0 & 1.3 & 1.8 & 0 & 1.8 & 2.8 & 0 & 0 \\
\hline Educational Services & 0 & 2.5 & 0 & 1.6 & 0 & 0 & 0 & 1.3 \\
\hline Health Care and Social Assistance & 0 & 1.9 & 0 & 6 & 0 & 3.2 & 0 & 1.7 \\
\hline Arts, Entertainment, and Recreation & 0 & 1.2 & 1.4 & 0 & 0 & 0 & 0 & 0 \\
\hline Accommodation and Food Services & 0 & 0 & 0 & 0 & 0 & 0 & 4.4 & 2.7 \\
\hline Other Services & 0 & 1.3 & 1.5 & 1.8 & 1.3 & 1.7 & 1.2 & 2.3 \\
\hline
\end{tabular}

Table 4 Characteristics associated with being an employer-firm

\begin{tabular}{|c|c|c|c|c|c|c|c|c|}
\hline Variable & white & & black & & Hispanic & & Asian & \\
\hline & male & female & male & female & male & female & male & female \\
\hline concentrate & $1.100^{\star \star \star}$ & $0.628^{\star \star \star}$ & $0.651^{* * *}$ & $0.484^{\star \star \star}$ & $0.745^{\star \star \star}$ & $0.497^{* \star *}$ & $1.115^{\star \star \star}$ & $1.071^{\star \star *}$ \\
\hline sole & $-1.997^{\star * \star}$ & $-2.124^{\star \star \star}$ & $-2.007^{\star \star \star}$ & $-1.826^{\star \star *}$ & $-2.152^{\star \star \star}$ & $-2.110^{\star \star *}$ & 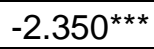 & $-2.221^{\star \star \star}$ \\
\hline $\begin{array}{l}\text { Acquire } \\
\text { before80 }\end{array}$ & 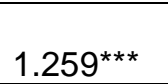 & $1.201^{\star \star \star}$ & $1.234^{\star \star \star}$ & $0.925^{\star \star \star}$ & $1.102^{\star \star \star}$ & 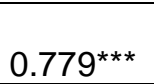 & $1.001^{\star \star *}$ & $0.838^{\star \star *}$ \\
\hline $\begin{array}{l}\text { Acquire } \\
1980-90\end{array}$ & $0.830^{\star \star \star}$ & $0.838^{\star \star \star}$ & $0.938^{\star \star \star}$ & $0.722^{\star \star \star}$ & 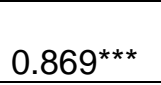 & $0.828^{\star \star \star}$ & $0.773^{\star \star \star}$ & $0.521^{\star \star \star}$ \\
\hline $\begin{array}{l}\text { Acquire } \\
1990-96\end{array}$ & $0.497^{\star \star \star}$ & $0.528^{\star \star \star}$ & 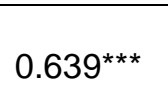 & $0.450^{\star \star \star}$ & $0.497^{\star \star \star}$ & $0.639 * \star \star$ & $0.421^{\star \star *}$ & $0.500^{\star \star \star}$ \\
\hline $\begin{array}{l}\text { Govern } \\
\text { loan }\end{array}$ & 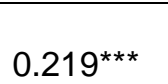 & $0.564^{\star \star \star}$ & $0.476^{\star \star \star}$ & $0.728^{\star \star \star}$ & $0.652^{\star \star \star}$ & $0.592^{\star \star}$ & $0.574^{\star \star \star}$ & $0.423^{*}$ \\
\hline
\end{tabular}




\begin{tabular}{|c|c|c|c|c|c|c|c|c|}
\hline $\begin{array}{l}\text { Family } \\
\text { funds }\end{array}$ & $-0.071^{* * *}$ & $-0.261 * \star *$ & $-0.203^{\star *}$ & -0.186 & $-0.141^{\star *}$ & $-0.215^{*}$ & -0.041 & 0.024 \\
\hline $\begin{array}{l}\text { Household } \\
\text { customer }\end{array}$ & $0.500^{\star \star \star}$ & $0.168^{\star \star \star}$ & -0.023 & 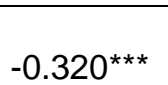 & $0.179 * \star \star$ & 0.027 & $0.323^{\star \star \star}$ & $0.213^{\star \star \star}$ \\
\hline $\begin{array}{l}\text { Business } \\
\text { customer }\end{array}$ & $0.318^{\star \star \star}$ & $0.439 * \star \star$ & $0.110^{*}$ & -0.15 & $0.144^{\star \star \star}$ & $0.273^{\star \star \star}$ & $0.181^{\star \star \star}$ & $0.267^{\star \star \star}$ \\
\hline Exporting & $-0.078^{* *}$ & $0.223^{\star \star \star}$ & $-0.609 * * *$ & -0.477 & $-0.233^{\star \star}$ & 0.176 & $-0.233^{\star \star}$ & -0.203 \\
\hline $25-34$ & $0.841^{\star \star \star}$ & $0.780^{\star \star \star}$ & 0.321 & 0.608 & $1.205^{\star \star \star}$ & $0.755^{\star \star}$ & $0.776^{\star \star \star}$ & $0.930^{\star \star \star}$ \\
\hline $35-44$ & $1.145^{\star \star \star}$ & 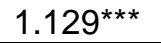 & $0.700^{\star \star}$ & $0.785^{\star}$ & $1.652^{\star \star \star}$ & $1.002^{\star \star \star}$ & 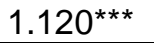 & $1.219 \star \star \star$ \\
\hline $45-54$ & $1.101^{\star \star \star}$ & $1.118^{\star \star \star}$ & $0.755^{\star \star}$ & $0.908^{\star \star}$ & $1.623^{\star \star \star}$ & $1.112^{\star \star \star}$ & $1.140 * \star \star$ & $1.180 * \star \star$ \\
\hline $55-64$ & $0.996^{\star * \star}$ & 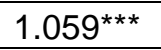 & $0.908^{\star \star \star}$ & $1.011^{\star *}$ & $1.614^{\star * \star}$ & $1.159 * * \star$ & $1.041^{\star \star \star}$ & $1.331^{\star \star \star}$ \\
\hline$>=65$ & $0.921^{\star \star \star}$ & $1.072^{\star \star \star}$ & $0.795^{\star \star}$ & $1.206^{\star \star \star}$ & $1.667^{* * *}$ & $1.395^{\star \star \star}$ & $0.963^{\star \star \star}$ & $1.245^{\star \star \star}$ \\
\hline $\begin{array}{l}\text { Hschool- } \\
\text { bachelor }\end{array}$ & $-0.072^{\star * \star}$ & $-0.198 * \star \star$ & $-0.291^{\star \star \star}$ & -0.105 & $-0.197^{\star \star \star *}$ & $-0.239 \star \star$ & 0.043 & 0.074 \\
\hline >=bachelor & $0.073^{\star * *}$ & -0.002 & $0.117^{*}$ & $0.318^{\star \star \star}$ & -0.032 & 0.098 & $0.295^{\star \star \star}$ & $0.370 \star \star \star *$ \\
\hline produce & $-0.365^{\star \star \star}$ & $-0.710^{\star \star \star}$ & $-0.489 * \star \star$ & $-0.714^{\star \star \star}$ & $-0.657^{\star \star \star}$ & $-0.938^{\star \star \star}$ & $-0.477^{* * *}$ & $-0.825^{\star * *}$ \\
\hline manage & $-0.181^{\star \star \star}$ & $-0.172^{\star \star \star}$ & -0.053 & $-0.186^{*}$ & -0.048 & $-0.250^{\star \star *}$ & $-0.175^{\star \star \star}$ & 0.001 \\
\hline finance & $0.403^{\star \star \star}$ & $0.704^{\star \star \star}$ & $0.634^{\star \star \star}$ & $0.811^{* * *}$ & $0.677^{\star \star \star}$ & 0.870 *** & 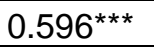 & $0.610 * \star \star$ \\
\hline $\begin{array}{l}\text { Other } \\
\text { function }\end{array}$ & 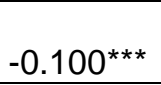 & $-0.236^{\star \star \star}$ & $-0.764^{\star \star \star}$ & $-1.113^{\star \star \star}$ & $-0.714^{\star \star \star}$ & $-0.863^{\star \star \star}$ & $-0.424^{\star \star \star}$ & $-0.381^{\star \star \star}$ \\
\hline$<40$ hours & $-1.562^{\star \star \star}$ & $-1.419 * \star \star$ & $-1.328^{\star \star \star}$ & $-1.479^{\star \star \star}$ & $-1.113^{\star \star \star}$ & $-1.373^{\star \star \star}$ & $-1.119^{\star \star \star}$ & $-1.155^{\star \star \star}$ \\
\hline cons & $-0.087^{*}$ & $0.232^{\star \star}$ & 0.328 & 0.434 & $-0.392^{*}$ & 0.33 & -0.191 & -0.454 \\
\hline $\mathrm{N}$ & 613922 & 152300 & 12920 & 6663 & 20865 & 7492 & 26372 & 9974 \\
\hline
\end{tabular}

Table 5. Characteristics associated with higher volume of sales, non-employer firms

\begin{tabular}{|c|c|c|c|c|c|c|c|c|}
\hline \multirow{2}{*}{ Variable } & \multicolumn{2}{|l|}{ white } & \multicolumn{2}{|l|}{ black } & \multicolumn{2}{|l|}{ Hispanic } & \multicolumn{2}{|l|}{ Asian } \\
\hline & male & female & male & female & male & female & male & female \\
\hline concentrate & $0.309 * \star \star$ & 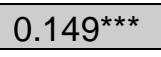 & $0.348^{\star \star \star}$ & $0.244^{\star \star \star}$ & $0.368^{\star \star \star}$ & $0.206^{\star \star \star}$ & $0.630^{\star \star \star}$ & $0.234^{\star \star \star}$ \\
\hline sole & 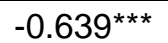 & $-0.516^{\star \star \star}$ & $-0.428^{\star \star \star}$ & $-0.301^{\star \star \star}$ & $-0.341^{\star \star \star}$ & $-0.403^{\star \star *}$ & $-0.315^{\star \star \star}$ & 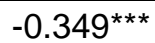 \\
\hline $\begin{array}{l}\text { Acquire } \\
\text { before80 }\end{array}$ & $0.187^{\star \star \star}$ & $0.407^{\star \star \star}$ & $0.369 * \star \star$ & $0.423^{\star *}$ & $0.275^{\star \star \star}$ & $0.272^{*}$ & $0.208^{*}$ & 0.09 \\
\hline $\begin{array}{l}\text { Acquire } \\
1980-90\end{array}$ & $0.245^{\star \star \star}$ & $0.408^{\star \star \star}$ & $0.414^{\star \star \star}$ & $0.395^{\star \star \star}$ & $0.466^{\star \star \star}$ & $0.679 * \star \star *$ & $0.267^{\star \star \star}$ & $0.364^{\star \star \star}$ \\
\hline $\begin{array}{l}\text { Acquire } \\
1990-96\end{array}$ & $0.247^{\star \star \star}$ & $0.323^{\star \star \star}$ & $0.313^{\star \star \star}$ & $0.409^{\star \star \star *}$ & $0.368^{\star \star \star}$ & $0.436^{\star \star *}$ & $0.221^{\star \star \star *}$ & $0.313^{\star * \star}$ \\
\hline $\begin{array}{l}\text { Govern } \\
\text { loan }\end{array}$ & $0.166^{\star \star \star}$ & $0.342^{\star * *}$ & 0 & $0.396^{*}$ & -0.098 & 0.054 & 0.246 & -0.042 \\
\hline Family & $-0.260^{\star \star \star}$ & $-0.083^{\star \star *}$ & $-0.188^{\star *}$ & $-0.156^{*}$ & $-0.133^{\star \star}$ & -0.115 & $-0.118^{*}$ & -0.094 \\
\hline
\end{tabular}




\begin{tabular}{|c|c|c|c|c|c|c|c|c|}
\hline funds & & & & & & & & \\
\hline $\begin{array}{l}\text { Household } \\
\text { customer }\end{array}$ & $-0.029 * \star \star$ & $-0.245^{\star \star \star}$ & $-0.289 \star \star \star *$ & $-0.422^{\star \star \star}$ & $-0.147^{\star \star \star}$ & $-0.248^{\star \star \star}$ & -0.053 & $-0.158^{\star \star \star}$ \\
\hline $\begin{array}{l}\text { Business } \\
\text { customer }\end{array}$ & $0.246^{\star \star \star}$ & $0.354^{\star \star \star}$ & $0.145^{\star \star}$ & $0.187^{\star *}$ & $0.073^{*}$ & $0.139 *$ & $0.156^{\star \star \star}$ & $0.244^{\star \star \star}$ \\
\hline Exporting & $0.254^{* * *}$ & 0.470 *** & 0.227 & -0.117 & $0.301^{\star \star \star}$ & $0.318^{\star}$ & $0.462^{\star \star \star}$ & $0.273^{\star}$ \\
\hline $25-34$ & $0.516^{\star \star \star}$ & $0.308^{\star \star \star}$ & 0.246 & 0.151 & $0.628^{\star \star \star}$ & $0.278^{*}$ & $0.279^{\star *}$ & $0.586^{\star \star \star}$ \\
\hline $35-44$ & $0.822^{* \star *}$ & $0.631^{* * *}$ & $0.425^{\star \star}$ & $0.360^{*}$ & $0.805^{\star \star \star}$ & $0.527^{* * *}$ & $0.511^{\star * *}$ & $0.840^{* * *}$ \\
\hline $45-54$ & 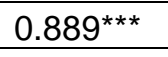 & $0.714^{\star \star \star}$ & $0.485^{\star \star}$ & $0.466^{* \star}$ & $0.688^{\star \star \star}$ & $0.501^{\star \star \star}$ & $0.585^{\star \star \star}$ & $0.994^{\star \star \star}$ \\
\hline $55-64$ & $0.909 * \star \star$ & $0.706^{\star \star \star}$ & 0.470 ** & $0.385^{\star}$ & $0.748^{\star \star \star}$ & $0.566^{\star \star \star}$ & $0.532^{\star \star \star}$ & $0.842^{\star \star \star}$ \\
\hline$>=65$ & $0.741^{\star \star \star}$ & $0.652^{\star \star \star}$ & $0.415^{\star}$ & $0.465^{\star}$ & $0.685^{\star \star \star}$ & $0.344^{\star}$ & $0.512^{\star \star \star}$ & $0.547^{\star \star}$ \\
\hline $\begin{array}{l}\text { Hschool- } \\
\text { bachelor }\end{array}$ & $-0.115^{\star \star \star}$ & $-0.064^{\star \star \star}$ & $-0.270^{\star \star \star}$ & -0.023 & $-0.162^{\star \star \star}$ & -0.072 & 0.04 & $-0.131^{*}$ \\
\hline$>=$ bachelor & 0 & $0.075^{\star \star \star}$ & $-0.137^{\star \star}$ & 0.075 & $-0.090^{\star}$ & 0.027 & 0.004 & $-0.108^{*}$ \\
\hline produce & $-0.632^{\star \star \star}$ & $-0.511^{\star \star \star}$ & $-0.405^{\star \star \star}$ & $-0.388^{\star \star \star}$ & $-0.418^{\star \star \star}$ & $-0.480 * \star \star$ & $-0.506^{\star \star \star}$ & $-0.515^{\star \star \star}$ \\
\hline manage & $-0.141^{\star \star \star}$ & $-0.198^{\star \star \star}$ & -0.051 & -0.037 & -0.034 & $-0.251^{\star \star \star}$ & -0.069 & -0.052 \\
\hline finance & $0.414^{\star \star \star}$ & $0.491^{\star \star *}$ & $0.414^{\star \star *}$ & $0.326^{\star \star \star}$ & $0.361^{\star \star *}$ & $0.510^{* \star *}$ & $0.374^{\star \star *}$ & $0.381^{* * *}$ \\
\hline $\begin{array}{l}\text { Other } \\
\text { function }\end{array}$ & $-0.343^{\star \star *}$ & $-0.284^{\star \star \star}$ & $-0.463^{\star \star *}$ & $-0.507^{\star \star *}$ & $-0.312^{\star \star *}$ & $-0.654^{\star \star *}$ & $-0.285^{\star \star \star}$ & $-0.423^{\star \star \star}$ \\
\hline$<40$ hours & $-1.128^{\star \star \star}$ & $-1.213^{\star \star \star}$ & $-1.251^{\star \star \star}$ & $-1.115^{\star \star \star}$ & $-1.210^{\star \star \star}$ & $-1.151^{\star \star \star}$ & $-1.044^{\star \star \star}$ & $-1.150^{\star \star \star}$ \\
\hline Cons & 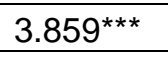 & $3.396^{\star \star \star}$ & $3.646^{\star \star \star}$ & $3.028^{\star \star \star}$ & $3.426^{\star \star \star}$ & $3.444^{\star \star \star}$ & $3.521^{\star \star \star}$ & $3.170^{\star \star \star}$ \\
\hline $\mathrm{N}$ & 201963 & 65848 & 6328 & 3845 & 9347 & 4141 & 9639 & 4878 \\
\hline
\end{tabular}

Table 6. Characteristics associated with higher sales volume per employee, employer firms

\begin{tabular}{|c|c|c|c|c|c|c|c|c|}
\hline Variable & \multicolumn{2}{|l|}{ white } & \multicolumn{2}{|l|}{ black } & \multicolumn{2}{|l|}{ Hispanic } & \multicolumn{2}{|l|}{ Asian } \\
\hline & male & female & male & female & male & female & male & female \\
\hline concentrate & $0.101^{* * *}$ & $-0.300 * \star \star *$ & $0.082^{*}$ & -0.024 & $0.123^{\star * *}$ & $-0.207^{* * \star}$ & $0.237^{* \star *}$ & $-0.276 * \star *$ \\
\hline sole & $-0.168^{\star \star \star}$ & $-0.158^{\star \star \star}$ & $-0.260^{\star \star \star}$ & $-0.203^{\star \star \star}$ & 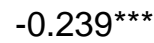 & $-0.310^{\star \star \star}$ & $-0.122^{\star \star \star}$ & $-0.162^{\star \star \star}$ \\
\hline $\begin{array}{l}\text { Acquire } \\
\text { before } 80\end{array}$ & $0.140^{\star \star \star *}$ & $0.236^{\star \star \star}$ & $0.161^{\star *}$ & $0.269^{\star \star}$ & $0.111^{\star \star}$ & 0.117 & $0.094^{\star \star}$ & 0.109 \\
\hline $\begin{array}{l}\text { Acquire } \\
1980-90\end{array}$ & $0.107^{\star \star \star}$ & $0.155^{\star \star \star}$ & $0.189^{\star * *}$ & $0.365^{\star \star \star}$ & $0.163^{\star \star *}$ & $0.248^{\star * *}$ & $0.094^{\star * *}$ & $0.141^{* *}$ \\
\hline $\begin{array}{l}\text { Acquire } \\
1990-96\end{array}$ & $0.076^{\star \star *}$ & $0.097^{\star \star \star}$ & $0.106^{* *}$ & $0.125^{\star}$ & $0.117^{\star \star \star}$ & $0.151^{\star \star \star}$ & $0.095^{\star \star \star}$ & $0.087^{*}$ \\
\hline $\begin{array}{l}\text { Govern } \\
\text { loan }\end{array}$ & $-0.134^{\star \star \star}$ & $-0.082^{\star \star \star}$ & 0.03 & $-0.287^{\star \star \star}$ & $-0.134^{*}$ & -0.016 & -0.067 & -0.008 \\
\hline Family & $0.011^{\star *}$ & -0.012 & $-0.075^{\star}$ & $-0.131^{*}$ & -0.026 & -0.028 & 0.046 & -0.025 \\
\hline
\end{tabular}




\begin{tabular}{|c|c|c|c|c|c|c|c|c|}
\hline funds & & & & & & & & \\
\hline $\begin{array}{l}\text { Household } \\
\text { customer }\end{array}$ & $-0.110^{\star \star \star}$ & $-0.096^{\star \star \star}$ & -0.026 & 0.026 & $-0.075^{\star \star \star}$ & $-0.083^{*}$ & $-0.090^{\star \star \star}$ & 0.041 \\
\hline $\begin{array}{l}\text { Business } \\
\text { customer }\end{array}$ & $0.094^{\star \star \star}$ & $0.137^{\star \star \star}$ & $0.065^{\star}$ & $0.245^{\star \star \star}$ & $0.100^{\star \star \star}$ & $0.118^{\star \star}$ & $0.183^{\star \star \star}$ & $0.109^{\star \star}$ \\
\hline Exporting & $0.250^{\star \star \star}$ & $0.301^{\star \star \star}$ & -0.039 & 0.122 & $0.555^{\star \star \star}$ & $0.582^{\star \star \star}$ & $0.439 * \star \star$ & $0.355^{\star \star \star}$ \\
\hline $25-34$ & $0.179^{\star \star \star}$ & -0.085 & -0.025 & -0.32 & 0.114 & -0.42 & 0.151 & 0.003 \\
\hline $35-44$ & $0.269 * \star \star$ & -0.018 & 0.04 & -0.209 & 0.194 & -0.464 & 0.238 & -0.013 \\
\hline $45-54$ & $0.276^{\star \star \star}$ & -0.018 & 0.072 & -0.216 & 0.15 & -0.493 & 0.172 & -0.039 \\
\hline $55-64$ & $0.247^{\star \star \star}$ & -0.044 & 0.003 & -0.35 & 0.198 & -0.52 & 0.13 & -0.078 \\
\hline$>=65$ & $0.225^{\star \star \star}$ & -0.021 & -0.104 & -0.371 & 0.109 & -0.362 & 0.098 & -0.166 \\
\hline $\begin{array}{l}\text { Hschool- } \\
\text { bachelor }\end{array}$ & -0.008 & $-0.043^{\star \star \star}$ & 0.07 & -0.081 & 0.046 & -0.054 & $0.124^{\star \star \star}$ & -0.007 \\
\hline >=bachelor & $0.102^{\star \star \star}$ & 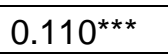 & $0.287^{\star \star \star}$ & $0.252^{\star \star \star}$ & $0.161^{\star \star \star}$ & 0.068 & $0.275^{\star \star \star}$ & $0.196^{\star \star \star}$ \\
\hline produce & $-0.212^{\star \star \star}$ & $-0.219 * \star \star *$ & $-0.148^{\star \star \star}$ & 0.013 & $-0.205^{\star \star \star}$ & $-0.140^{\star \star \star}$ & $-0.155^{\star \star \star}$ & $-0.195^{\star \star \star}$ \\
\hline manage & $-0.044^{\star \star \star}$ & $-0.171^{\star \star \star}$ & $-0.070^{*}$ & $-0.108^{*}$ & $-0.092^{\star * \star}$ & $-0.097^{*}$ & -0.028 & $-0.088^{*}$ \\
\hline finance & $0.058^{\star \star \star}$ & $0.091^{\star \star \star}$ & $0.078^{\star}$ & $0.145^{\star \star}$ & $0.102^{\star \star \star}$ & $0.111^{* \star}$ & $0.079 * \star \star$ & 0.059 \\
\hline $\begin{array}{l}\text { Other } \\
\text { function }\end{array}$ & $0.137^{\star \star \star}$ & $0.233^{\star \star \star}$ & $0.252^{\star \star}$ & 0.178 & $0.129^{*}$ & 0.07 & 0.075 & 0.114 \\
\hline$<40$ hours & $-0.317^{\star \star \star}$ & $-0.296^{\star \star \star}$ & $-0.323^{\star \star \star}$ & $-0.191^{\star \star \star}$ & $-0.298^{\star * *}$ & $-0.239 * * *$ & $-0.287^{\star \star \star}$ & $-0.205^{\star \star \star}$ \\
\hline _cons & $4.507^{\star \star \star}$ & $4.562^{\star \star \star}$ & $4.305^{\star \star \star}$ & $4.091^{\star \star \star}$ & $4.412^{\star \star \star}$ & $4.904^{\star \star \star}$ & $4.190^{\star \star \star}$ & $4.604^{\star \star \star}$ \\
\hline $\mathrm{N}$ & 368146 & 74378 & 5508 & 2252 & 9768 & 2724 & 14329 & 4253 \\
\hline
\end{tabular}

